\title{
Managing the Competitiveness of Moscow Underground (Metro) Based on Consumer Satisfaction
}

\author{
Irina Lopatinskaya, Natalia Ivashkova, Galina Timokhina, Irina Skorobogatykh, \\ Irina Shirochenskaya and Olga Grineva
}

Plekhanov Russian University of Economics, Moscow, Russia

Correspondence should be addressed to: Irina Skorobogatykh; Skorobogatykh.II@rea.ru

Received date:18 September 2020; Accepted date: 20 January 2021; Published date: 25 March 2021

Copyright (C) 2021. Irina Lopatinskaya, Natalia Ivashkova, Galina Timokhina, Irina Skorobogatykh, Irina Shirochenskaya and Olga Grineva. Distributed under Creative Commons Attribution 4.0 International CCBY 4.0

\begin{abstract}
This article presents an original methodology of consumer assessments of satisfaction with the quality of a product/service based on N. Kano's model; the article describes a study of customer satisfaction with the technical quality of Moscow underground (metro) services carried out in accordance with the methodology developed by the authors aimed at justifying management decisions to increase the competitiveness of metro system. Within the framework of the author's methodology, the relative importance of product attributes, including rail transport services, was determined; the calculation of descriptive statistics indicators for each attribute was carried out; for each attribute, the indices of influence on passengers' satisfaction and dissatisfaction with services were calculated according to R. Best method; the total index of attribute influence on consumer satisfaction was determined; the matrix for interpreting quality categories developed by M. Timko was modified; as well as a comprehensive determination of the impact of an attribute on consumer satisfaction. This methodology makes it possible to highlight problem points in the competitiveness of services and make management decisions to improve them. The authors propose the following management solutions to improve the competitiveness of Moscow underground (metro) services based on the developed methodology: making capital investments in the introduction of important and attractive attributes of technical quality of Moscow underground (metro) services for consumers; reducing costs of introducing quality attributes that are indifferent to consumers; increasing the presence of one-dimensional attributes of technical quality of Moscow metro services; monitoring technical quality attributes of a service and studying their perception by consumers.

Keywords: Assessments of Satisfaction, Technical Quality, Underground Services, Methodology.
\end{abstract}

Cite this Article as: Irina Lopatinskaya, Natalia Ivashkova, Galina Timokhina, Irina Skorobogatykh, Irina Shirochenskaya and Olga Grineva (2021)," Managing the Competitiveness of Moscow Underground (Metro) Based on Consumer Satisfaction ", Journal of Eastern Europe Research in Business and Economics Vol. 2021 (2021), Article ID 126026, DOI: 10.5171/2021.126026 


\section{Introduction}

In the context of the intense functional competition of various types of transport services, an indisputable and extremely urgent task of market economic entities is to manage the competitiveness of these services. The competitiveness of transport services, in particular, rail transport services, is understood as a higher ratio of the aggregate of quality characteristics, costs of its acquisition and consumption, as compared to goods/services-substitutes, when they meet market requirements (Mokronosov \& Mavrina, 2014; Sidorchuk \& Skorobogatykh, 2015).

The results of the international and Russian scientific research substantiate and confirm that the key factor in ensuring and improving the competitiveness of any goods and services, including rail transport services, is their compliance with market requirements, that is, the needs, expectations, preferences, and values of potential and actual consumers of these services (De Oña, R. et al., 2016; Eboli, Fu \& Mazzulla, 2016; Seifullaeva et al., 2018; Seifullaeva et al., 2018) and others.

Since the set of behavioral variables of each individual consumer is formed under the influence of a wide range of factors, consumer assessments of the same type of transport service made by different consumers may not coincide. Each consumer will assess the level of competitiveness of services, in particular, services of rail modes of transport, purely individually (Friman \& Fellesson, 2009; Ivashkova, et al., 2009). The competitiveness of a service is determined, in contrast to its quality, by a combination of only those specific properties that are of clear interest to a given consumer and which ensure the satisfaction of this specific need, while other characteristics of the service may not be taken into account.
Accordingly, the starting point in the formation and improvement of the competitiveness of services, including rail transport services, is the study of various consumer behavior variables, including passenger satisfaction of specific needs when consuming these services (Givoni \& Rietveld, 2007).

World and Russian experience in measuring consumer satisfaction ratings with the quality of rail transport services is represented by a certain variety of methods and techniques that make it possible to highlight problem points in the competitiveness of a service and make management decisions to improve it (Geetika, 2010; Eboli \& Mazzulla, 2012; Sidorchuk \& Skorobogatykh, 2015; Sidorchuk, et al., 2015; De Oña, et al., 2016; Fraszczyk \& Marinov, 2017; Machado-Leóna, et al, 2017; Seifullaeva, et al., 2018; Lukina, et al., 2018; 2019; Ibrahim, et al., 2020; Jomnonkwao, et al, 2020). At the same time, due to the dynamics of scientific research and the emergence of new links and relationships between their components, the strategy of scientific search for methodology and research on the problems of providing and increasing the competitiveness of rail transport services based on the study of consumer ratings is changing.

\section{Project Goals}

The purpose of this research is to develop an original methodology for consumer satisfaction ratings with the quality of goods/services based on N. Kano's model and to study consumer satisfaction with the technical quality of services of the Moscow underground (metro) according to the author's methodology in order to justify management decisions of increasing its competitiveness. 


\section{Author's Methodology}

The authors developed an original methodology for consumer ratings of service quality based on a model for analyzing attributes and their impact on consumer perception of a complete product by N. Kano. According to N. Kano's methodology, based on the study of the consumer's reaction to the presence and absence of a product attribute (feature), it is determined how this attribute will affect the consumer satisfaction or dissatisfaction with the product as a whole (Cowell, 1984; Grönroos, 1998).
Kano's methodology involves classifying product attributes in order to determine the degree of their impact on customer satisfaction or dissatisfaction. Kano's model includes five quality categories (dimensions), each of which characterizes a special relationship between the quality of performance of a product attribute and customer satisfaction/dissatisfaction, as well as the sixth category, which covers contradictory and questionable answers from respondents (Table 1).

\section{Table 1: classification of product attributes by Kano Model}

\begin{tabular}{|l|c|}
\hline Category & $\mathrm{M}$ \\
\hline Must-be (basic) & $\mathrm{A}$ \\
\hline Attractive (desired/factors of delight) & $\mathrm{O}$ \\
\hline One-dimensional (attributes of quality) & $\mathrm{R}$ \\
\hline Reverse & $\mathrm{I}$ \\
\hline Indifferent & $\mathrm{Q}$ \\
\hline Questionable result & \\
\hline
\end{tabular}

The first three categories of attributes are considered basic, since their contribution to satisfaction/dissatisfaction can be indented. The category of "questionable" attributes is excluded from the analysis, since the respondents' answers are contradictory and impossible to interpret. A large proportion of reverse attributes that are irrelevant and questionable are likely to indicate errors in the preparation of the questionnaire: they are either too general or, on the contrary, too detailed in formulation (Berger, et al., 1993). The sequence of research by the Kano method is described in detail in a number of researches (Berger, et al., 1993; Tsysar, 2002; Lopatinskaya, et al., 2015).

In order to assign an attribute to a specific category, the authors developed an original methodology which consists of the following steps:

1. Determining the relative importance of an attribute. The Kano method does not directly assess the importance of attributes. However, we assume that those attributes whose perception is determined are more important; that is, when respondents can assign an attribute to one of the three main quality categories: basic, onedimensional, or attractive factors. Therefore, the important attributes are those for which the equation is the following: $(\mathrm{O}+\mathrm{A}+\mathrm{M})>(\mathrm{I}+\mathrm{R}+\mathrm{Q})$.

2. Calculating descriptive statistics. Fractions, modes, and standard deviation were calculated for each attribute.

3. Calculating the indices of influence on satisfaction. For each attribute, the indices of influence on passenger satisfaction (SII) and dissatisfaction (DDI) were calculated according to the method of R. Best, as well as the aggregate satisfaction impact index (CSI).

4. Building a modified matrix for interpreting quality categories. The authors 
propose to expand the graphical interpretation of quality categories developed by $M$. Timko by including two additional indicators: the relative importance of the attribute (the total share of responses in categories $\mathrm{A}, \mathrm{O}, \mathrm{M}$ ) and the consistency of attribute ratings, which will improve classification accuracy and the information content of the graphical presentation. In order to use it on an existing matrix, the size of the point that characterizes the attribute position (the percentage of responses $\mathrm{O}+\mathrm{A}+\mathrm{M}$ ) and the color of the point (the value of the standard deviation) should be added.

5. Comprehensively determining the attribute's impact on satisfaction based on graphical analysis and descriptive statistics. The comprehensive determination of the impact of an attribute on satisfaction is based on a graphical analysis and descriptive statistics.

Thus, the methodology developed by the authors will make it possible to determine consumer satisfaction with the technical quality of the underground (metro) services, which will allow formulating recommendations for making management decisions in order to increase the competitiveness of the Moscow metro services.

For the study, passengers of the Moscow metro (46\% men and 24\% women) were selected as sample units, the sample size was 461 units.

\section{Research Results}

The survey showed that the average customer satisfaction with the technical quality of metro services is 3.8 points on a five-point scale. The share of satisfied respondents is $63.1 \%$, including a quarter of respondents (56\%) fully satisfied with the technical quality of metro services. More than half of respondents believe that there is enough equipment for cars and trains and/or nothing else they can offer.

According to the author's methodology, four groups of important attributes of the technical quality of Moscow underground (metro) services were identified, (see table 2).

Table 2: The importance of technical quality attributes of Moscow underground (metro) services

\begin{tabular}{|l|c|}
\hline Attributes & $\begin{array}{c}\text { The total share of basic, one- } \\
\text { dimensional and attractive } \\
\text { factors according to Kano, } \%\end{array}$ \\
\hline Most important attributes & Over $65 \%$ \\
\hline Electronic display indicating the next station & 85 \\
Working air conditioner & 81 \\
Availability of Wi-Fi & 73 \\
Separation of side seats by configuration or partition & 69 \\
Sound insulation & 69 \\
Space for strollers, bicycles and bulky luggage & 68 \\
\hline Important attributes & $51-65 \%$ \\
\hline
\end{tabular}

Irina Lopatinskaya, Natalia Ivashkova, Galina Timokhina, Irina Skorobogatykh, Irina Shirochenskaya and Olga Grineva, Journal of Eastern Europe Research in Business and Economics, DOI: 10.5171/2021.126026 


\begin{tabular}{|l|c|}
\hline Leaning seats & 63 \\
Seat type: soft, springy & 61 \\
USB charges for smartphones & 60 \\
Allocated space for standing & 59 \\
The scheme of allocation of seats & 59 \\
Informing about the load of cars for the arriving train & 57 \\
Feeling of air movement, light blowing & 57 \\
Pass-through between the train cars & 57 \\
Interactive panel for setting the route in the car & 55 \\
\hline The least important attributes & $41-50 \%$ \\
\hline Window leaf or the possibility to open a window & $47 \%$ \\
Separation of seats by handrails & $46 \%$ \\
Type of finish seat leatherette or fabric & $45 \%$ \\
Configuration: wider seat spacing & $41 \%$ \\
\hline Unimportant or questionable attributes & Less than $40 \%$ or with a high \\
& proportion of reverse factors \\
\hline Temperature control in the car at the request of & $42 / 27$ \\
passengers & $37 / 14$ \\
Increased glazing area & $36 / 32$ \\
Additional vertical handrails: at the edges and in the & $31 / 25$ \\
middle of the sofas & $22 / 38$ \\
Adjusting the type of lighting & $22 / 19$ \\
Luggage racks above the seats & $17 / 18$ \\
The vertical rail & \\
Additional board on the side of the carriage indicating the & 8 / \\
terminal station & \\
Opening doors with a button & \\
\hline
\end{tabular}

The most important group includes six technical quality attributes of Moscow underground (metro) services with a total share of basic, one-dimensional and attractive attributes of more than $65 \%$. The most definite attributes were of passengers' opinions regarding the presence of an electronic display indicating the next station, working air conditioner and the availability of Wi-Fi. The important group includes nine technical quality attributes of metro services, for which the total share of basic, onedimensional and attractive attributes exceeds the share of questionable and reverse estimates.

Four attributes are considered the least important. Here, respondents' opinions are split roughly in half: about half of the respondents classify these attributes as factors that influence satisfaction or dissatisfaction. While about the same number of respondents attribute them to uncertain, reverse, or questionable factors. Attributes that have little impact on passenger satisfaction and/or have a high proportion of reverse factors (more than $25 \%$ ) are allocated to a separate group.

The technical quality attributes of Moscow underground (metro) services were classified based on the Kano model. Of the 27 technical quality attributes of Moscow metro services, a group of three attributes stands out: "Air conditioning", "Electronic display indicating the next station" and "Availability of Wi-Fi". These are the most important attributes (the share of $\mathrm{O}+\mathrm{A}+\mathrm{M}$ is maximum), the estimates for which are most consistent (standard deviation <1). The CSI Satisfaction Index has a value close to zero, since these attributes have an equally strong 
influence on both passenger satisfaction and dissatisfaction. This clearly characterizes these attributes as one-dimensional according to the Kano model.

The following three attributes, which were also ranked as the most important "Separation of side seats by configuration or partition", "Space for strollers, bicycles and bulky luggage", "sound insulation" - are evaluated in a similar way.

Consistency estimates for the "sound insulation" attribute are contradictory: if the presence of increased sound insulation is attractive to respondents, then the standard noise level is rated by some respondents as normal, and by others as unacceptable.

Therefore, the "sound insulation" attribute has a high share of ratings both as attractive and as a one-dimensional factor. Taking into account the mode values, this attribute has been assigned to the one-dimensional category.

Thus, six attributes of the technical quality of Moscow underground (metro) services are classified as one-dimensional (table 3). These attributes affect passenger satisfaction based on the "more is better" principle.

\section{Table 3: characteristics of a group of "one-dimensional" technical quality attributes of Moscow underground (metro) services}

\begin{tabular}{|c|c|c|c|c|c|c|c|c|c|c|c|c|c|}
\hline \multirow{2}{*}{ Attribute } & \multirow{2}{*}{$\begin{array}{c}\text { Bas } \\
\text { e, } \\
\text { pe } \\
\text { opl } \\
\text { e. }\end{array}$} & \multirow{2}{*}{$\begin{array}{c}\text { Mod } \\
\text { e }\end{array}$} & \multirow{2}{*}{$\begin{array}{c}\text { Stan } \\
\text { dar } \\
\text { d } \\
\text { devi } \\
\text { atio } \\
\text { n }\end{array}$} & \multirow{2}{*}{$\begin{array}{c}\text { Pro } \\
\text { port } \\
\text { ion } \\
\text { of } \\
\text { A0 } \\
\text { M, } \\
\% \\
\end{array}$} & \multicolumn{6}{|c|}{$\begin{array}{c}\text { Proportion of Kano } \\
\text { categories \% }\end{array}$} & \multirow{2}{*}{$\begin{array}{l}\text { SI } \\
\text { I, } \\
\%\end{array}$} & \multirow{2}{*}{$\begin{array}{l}\text { DD } \\
\text { I, } \\
\%\end{array}$} & \multirow{2}{*}{$\begin{array}{c}\text { CSI, } \\
\%\end{array}$} \\
\hline & & & & & A & 0 & M & $\mathrm{I}$ & $\mathrm{R}$ & Q & & & \\
\hline $\begin{array}{l}\text { Electronic display } \\
\text { indicating the next } \\
\text { station }\end{array}$ & 458 & 0 & 0,8 & 85 & 16 & $\begin{array}{l}4 \\
8\end{array}$ & $\begin{array}{l}2 \\
1\end{array}$ & $\begin{array}{l}1 \\
3\end{array}$ & 1 & 1 & 65 & -71 & -6 \\
\hline Air conditioner & 452 & 0 & 1,0 & 81 & 18 & $\begin{array}{l}4 \\
8\end{array}$ & $\begin{array}{l}1 \\
6\end{array}$ & $\begin{array}{l}1 \\
4\end{array}$ & 4 & 1 & 66 & -68 & -3 \\
\hline Availability of Wi-Fi & 457 & 0 & 0,9 & 73 & 12 & $\begin{array}{l}5 \\
1\end{array}$ & $\begin{array}{l}1 \\
0\end{array}$ & $\begin{array}{l}2 \\
5\end{array}$ & 2 & 0 & 64 & -62 & 1 \\
\hline $\begin{array}{l}\text { Separation of side } \\
\text { seats by configuration } \\
\text { or partition }\end{array}$ & 458 & 0 & 1,1 & 69 & 16 & $\begin{array}{l}3 \\
8\end{array}$ & $\begin{array}{l}1 \\
6\end{array}$ & $\begin{array}{l}2 \\
4\end{array}$ & 6 & 0 & 54 & -60 & -6 \\
\hline Sound insulation & 459 & 0 & 1,2 & 69 & 30 & $\begin{array}{l}3 \\
3\end{array}$ & 6 & $\begin{array}{l}1 \\
8\end{array}$ & 8 & 5 & 67 & -49 & 18 \\
\hline $\begin{array}{l}\text { Space for strollers, } \\
\text { bicycles and bulky } \\
\text { luggage }\end{array}$ & 457 & 0 & 1,0 & 68 & 15 & $\begin{array}{l}3 \\
7\end{array}$ & $\begin{array}{l}1 \\
6\end{array}$ & $\begin{array}{l}2 \\
7\end{array}$ & 4 & 1 & 53 & -58 & -4 \\
\hline
\end{tabular}

Seven technical quality attributes of Moscow underground (metro) services were assigned to the "attractive" group (table 4). These attributes make a big contribution to the formation of satisfaction, at the same time; passengers will not be dissatisfied with the absence of such attributes. Attributes are relatively important for the " $\mathrm{O}+\mathrm{A}+\mathrm{M}$ share" 
indicator, although the share of "indifferent" estimates is high. The consensus level is average, except for seat type ratings, where the standard deviation is high.

Table 4: characteristics of the group of "attractive" technical quality attributes of Moscow underground (metro) services

\begin{tabular}{|c|c|c|c|c|c|c|c|c|c|c|c|c|c|}
\hline \multirow[b]{2}{*}{ Attribute } & \multirow{2}{*}{$\begin{array}{c}\text { Ba } \\
\text { se, } \\
\text { pe } \\
\text { opl } \\
\text { e. }\end{array}$} & \multirow[b]{2}{*}{$\begin{array}{c}\text { Mod } \\
\text { e }\end{array}$} & \multirow{2}{*}{$\begin{array}{c}\text { Sta } \\
\text { nd } \\
\text { ard } \\
\text { de } \\
\text { via } \\
\text { tio } \\
\text { n }\end{array}$} & \multirow{2}{*}{$\begin{array}{c}\text { Pro } \\
\text { por } \\
\text { tion } \\
\text { of } \\
\text { A0 } \\
\text { M, } \\
\% \\
\end{array}$} & \multicolumn{6}{|c|}{$\begin{array}{c}\text { Proportion of Kano } \\
\text { categories \% }\end{array}$} & \multirow[b]{2}{*}{$\begin{array}{l}\text { SII } \\
\% \\
\%\end{array}$} & \multirow[b]{2}{*}{$\begin{array}{l}\text { DD } \\
\text { I, } \\
\%\end{array}$} & \multirow[b]{2}{*}{$\begin{array}{l}\text { CSI } \\
, \%\end{array}$} \\
\hline & & & & & A & 0 & M & I & $\mathrm{R}$ & Q & & & \\
\hline Leaning seats & $\begin{array}{c}45 \\
6\end{array}$ & 0 & 1,1 & 63 & 27 & $\begin{array}{l}2 \\
7\end{array}$ & 9 & 30 & 5 & 1 & 55 & -42 & 13 \\
\hline Seat type: soft, springy & $\begin{array}{c}45 \\
9\end{array}$ & 0 & 1,2 & 61 & 31 & $\begin{array}{l}2 \\
6\end{array}$ & 4 & 28 & 9 & 2 & 58 & -40 & 19 \\
\hline $\begin{array}{l}\text { USB charges for } \\
\text { smartphones }\end{array}$ & $\begin{array}{c}45 \\
8\end{array}$ & 0 & 1,1 & 60 & 26 & $\begin{array}{l}3 \\
1 \\
\end{array}$ & 3 & 36 & 3 & 1 & 56 & -38 & 19 \\
\hline $\begin{array}{l}\text { Allocated space for } \\
\text { standing }\end{array}$ & $\begin{array}{c}45 \\
7\end{array}$ & A & 1,2 & 59 & 37 & $\begin{array}{l}1 \\
6\end{array}$ & 7 & 28 & 10 & 3 & 54 & -33 & 21 \\
\hline $\begin{array}{l}\text { Informing about the } \\
\text { load of cars for the } \\
\text { arriving train }\end{array}$ & $\begin{array}{c}45 \\
7\end{array}$ & 0 & 1,1 & 57 & 31 & $\begin{array}{l}2 \\
3\end{array}$ & 4 & 36 & 5 & 1 & 54 & -32 & 22 \\
\hline $\begin{array}{l}\text { Pass-through between } \\
\text { the train cars }\end{array}$ & $\begin{array}{c}45 \\
9 \\
\end{array}$ & 0 & 1,2 & 57 & 32 & $\begin{array}{l}2 \\
0 \\
\end{array}$ & 5 & 33 & 7 & 3 & 54 & -33 & 20 \\
\hline $\begin{array}{l}\text { Interactive panel for } \\
\text { setting the route in the } \\
\text { car }\end{array}$ & $\begin{array}{c}45 \\
6\end{array}$ & I & 1,0 & 55 & 30 & $\begin{array}{l}2 \\
2\end{array}$ & 2 & 42 & 3 & 0 & 53 & -28 & 25 \\
\hline
\end{tabular}

It should be noted that this group does not have uniquely attractive attributes in the sense that N. Kano referred to this category as "delight factors": the upper quadrant of the matrix (maximum SII with minimum DDI) is free. The group inclines to the zone of "indifferent" attributes.

The next group includes attributes that should or should not be used when consuming Moscow metro services: must-be factors and reverse factors. The category of "reverse action" is uniquely related to the attribute "Opening doors with a button"; while the opinions of the respondents are quite consistent (standard deviation is average). Its influence on increasing satisfaction tends to zero, while its influence on the growth of dissatisfaction is maximal. If, following D. Shen's remarks, the respondents' answers for the attribute are recalculated with the opposite value ("Automatic door opening"), then such an attribute will fall into the first category important one-dimensional attributes (table 5). 
Table 5: characteristics of the "reverse" technical quality attributes of Moscow underground (metro) services and alternative (opposite in value) attributes

\begin{tabular}{|c|c|c|c|c|c|c|c|c|c|c|c|c|c|}
\hline \multirow[b]{2}{*}{ Attribute } & \multirow{2}{*}{$\begin{array}{c}\text { Ba } \\
\text { se, } \\
\text { pe } \\
\text { opl } \\
\text { e. }\end{array}$} & \multirow[b]{2}{*}{$\begin{array}{c}\text { Mod } \\
\text { e }\end{array}$} & \multirow{2}{*}{$\begin{array}{c}\text { Sta } \\
\text { nd } \\
\text { ard } \\
\text { de } \\
\text { via } \\
\text { tio } \\
\text { n }\end{array}$} & \multirow{2}{*}{$\begin{array}{c}\text { Pro } \\
\text { por } \\
\text { tion } \\
\text { of } \\
\text { A0 } \\
\text { M, } \\
\%\end{array}$} & \multicolumn{6}{|c|}{$\begin{array}{c}\text { Proportion of Kano } \\
\text { categories \% }\end{array}$} & \multirow[b]{2}{*}{$\begin{array}{c}\text { SII } \\
\text { \% }\end{array}$} & \multirow[b]{2}{*}{$\begin{array}{c}\text { DD } \\
\text { I, } \\
\%\end{array}$} & \multirow[b]{2}{*}{$\begin{array}{l}\text { CSI } \\
, \%\end{array}$} \\
\hline & & & & & A & 0 & M & I & $\mathrm{R}$ & $Q$ & & & \\
\hline \multicolumn{14}{|l|}{ Reverse } \\
\hline $\begin{array}{l}\text { Opening doors with a } \\
\text { button }\end{array}$ & $\begin{array}{c}45 \\
9 \\
\end{array}$ & $\mathrm{R}$ & 1,2 & 8 & 6 & 1 & 1 & $\begin{array}{l}1 \\
8 \\
\end{array}$ & 67 & 7 & 8 & -74 & -65 \\
\hline \multicolumn{14}{|l|}{ One-dimension } \\
\hline $\begin{array}{l}\text { Automatic door } \\
\text { opening }\end{array}$ & $\begin{array}{c}45 \\
9\end{array}$ & 0 & 1,2 & 67 & $\begin{array}{l}2 \\
5 \\
\end{array}$ & $\begin{array}{l}3 \\
1 \\
\end{array}$ & 12 & $\begin{array}{l}1 \\
8\end{array}$ & 8 & 7 & 59 & -54 & 5 \\
\hline \multicolumn{14}{|l|}{ Reverse } \\
\hline $\begin{array}{l}\text { Luggage racks above } \\
\text { the seats }\end{array}$ & $\begin{array}{c}45 \\
7 \\
\end{array}$ & $\mathrm{I} / \mathrm{R}$ & 1,4 & 22 & $\begin{array}{l}1 \\
1 \\
\end{array}$ & 8 & 4 & $\begin{array}{r}3 \\
8 \\
\end{array}$ & 38 & 2 & 18 & -50 & -32 \\
\hline \multicolumn{14}{|l|}{ "Indifferent" } \\
\hline $\begin{array}{l}\text { No luggage racks } \\
\text { above the seats }\end{array}$ & $\begin{array}{c}45 \\
7 \\
\end{array}$ & $\mathrm{I} / \mathrm{R}$ & 1,4 & 38 & 6 & $\begin{array}{l}2 \\
2 \\
\end{array}$ & 10 & $\begin{array}{l}3 \\
8 \\
\end{array}$ & 22 & 2 & 28 & -55 & -27 \\
\hline \multicolumn{14}{|l|}{ Reverse } \\
\hline Type of finish - fabric & $\begin{array}{c}45 \\
8\end{array}$ & I & 1,2 & 9 & 4 & 4 & 2 & $\begin{array}{l}2 \\
8\end{array}$ & 61 & 2 & 7 & -68 & -60 \\
\hline \multicolumn{14}{|l|}{ "Indifferent" } \\
\hline $\begin{array}{l}\text { Type of finish - } \\
\text { leatherette }\end{array}$ & $\begin{array}{c}45 \\
8\end{array}$ & I & 1,2 & 45 & $\begin{array}{l}1 \\
5 \\
\end{array}$ & $\begin{array}{l}1 \\
9 \\
\end{array}$ & 11 & $\begin{array}{l}4 \\
1 \\
\end{array}$ & 8 & 5 & 36 & -40 & -4 \\
\hline
\end{tabular}

Similarly, the attributes "Luggage Racks above the seats" and "Type of finish - fabric" can be classified as "reverse" attributes. However, they have a high percentage of" "indifferent" ratings. Therefore, when analyzing the alternatives "No Luggage racks above the seats" and "type of finish (leatherette)", the latter are more likely to be included in the group of attributes "indifferent" than "one-dimensional". It should be noted that in a qualitative study, respondents mentioned that the fabric wears out and gets dirty rather quickly, so even new cars with fabric seats can look untidy.

The "must-be" attributes were attributed to the climate control attributes in the car "Feeling of air movement" and "Window leaf/possibility to open a window", as well as "The standard scheme of seat allocation" (table 6). 
Table 6: characteristics of the group of "basic/must-be" technical quality attributes of Moscow underground (metro) services

\begin{tabular}{|c|c|c|c|c|c|c|c|c|c|c|c|c|c|}
\hline \multirow{2}{*}{ Attribute } & \multirow{2}{*}{$\begin{array}{l}\text { Bas } \\
\text { e, } \\
\text { peo } \\
\text { ple. }\end{array}$} & \multirow{2}{*}{$\begin{array}{c}\text { Mod } \\
\text { e }\end{array}$} & \multirow{2}{*}{$\begin{array}{c}\text { Sta } \\
\text { nda } \\
\text { rd } \\
\text { dev } \\
\text { iati } \\
\text { on } \\
\end{array}$} & \multirow{2}{*}{$\begin{array}{c}\text { Pro } \\
\text { port } \\
\text { ion } \\
\text { of } \\
\text { AOM } \\
, \% \\
\end{array}$} & \multicolumn{6}{|c|}{$\begin{array}{c}\text { Proportion of Kano } \\
\text { categories \% }\end{array}$} & \multirow{2}{*}{$\begin{array}{l}\text { SII } \\
, \%\end{array}$} & \multirow{2}{*}{$\begin{array}{l}\text { DD } \\
\text { I, } \\
\%\end{array}$} & \multirow{2}{*}{$\begin{array}{c}\text { CSI, } \\
\%\end{array}$} \\
\hline & & & & & A & 0 & M & I & $\mathrm{R}$ & Q & & & \\
\hline \multicolumn{14}{|l|}{ Basic/Must-be } \\
\hline $\begin{array}{l}\text { Feeling of air movement, } \\
\text { light blowing }\end{array}$ & 456 & 0 & 1,2 & 59 & $\begin{array}{l}1 \\
2\end{array}$ & $\begin{array}{l}2 \\
8\end{array}$ & 17 & $\begin{array}{l}3 \\
2\end{array}$ & 17 & 1 & 41 & -51 & -15 \\
\hline $\begin{array}{l}\text { Window leaf/possibility } \\
\text { to open a window }\end{array}$ & 456 & 0 & 1,4 & 57 & $\begin{array}{l}1 \\
3\end{array}$ & $\begin{array}{l}2 \\
3\end{array}$ & 10 & $\begin{array}{l}3 \\
6\end{array}$ & 17 & 1 & 37 & -56 & -14 \\
\hline $\begin{array}{l}\text { The standard scheme of } \\
\text { seat allocation ("sofas") }\end{array}$ & 456 & 0 & 1,2 & 47 & $\begin{array}{l}1 \\
1 \\
\end{array}$ & $\begin{array}{l}2 \\
6 \\
\end{array}$ & 22 & $\begin{array}{l}2 \\
4 \\
\end{array}$ & 15 & 3 & 38 & -64 & -27 \\
\hline \multicolumn{14}{|l|}{ Reverse } \\
\hline $\begin{array}{l}\text { Seats are arranged one } \\
\text { behind the other (as in } \\
\text { buses) }\end{array}$ & 456 & $\mathrm{R}$ & 1,2 & 15 & $\begin{array}{l}1 \\
3\end{array}$ & 2 & 0 & $\begin{array}{l}2 \\
4\end{array}$ & 58 & 3 & 15 & -62 & -47 \\
\hline
\end{tabular}

The attribute "Seats are arranged one behind the other (as in buses)" was classified with the opposite value. As can be seen, the "bus" seat arrangement is perceived as an attribute of reverse action and has a high potential for growing discontent.

The remaining attributes are included in the "indifferent" or "questionable" attribute group. For these attributes, the percentage of "indifferent" assessments is maximal, with an average consistency of respondents' opinions. This means that the introduction of these attributes will have little impact on passenger satisfaction, although this impact is positive (relatively high CSI index).

The group of "questionable" attributes included, firstly, the attributes on which the opinions of the respondents differed greatly. The range of answers is great (standard deviation > 1.4) for the attributes "Separation of seats with handrails", "Temperature control" and "Vertical handrail in the center of the car". Secondly, attributes with a high proportion of "dubious" (contradictory) assessments are included in the questionable group. In the authors' opinion, this is due to the novelty of the attributes "Lighting control by time of day", "Additional handrails at the edges and in the middle of the car", "Additional board on the side of the carriage indicating the terminal station".

These attributes were used by interviewers to provide most of the passengers' explanations, who use the "old" cars. A more detailed assessment can be given by comparing passengers' responses - those who are already familiar with these attributes (sample for "new" cars) with the answers of respondents who learned about such an attribute from the interviewer.

Table 7 summarizes the results of the technical quality attributes of Moscow underground (metro) services classification based on the Kano model.

For convenience, additional alternatives are given for a number of attributes (for example, “Upholstery Type"), in italics. 
Table 7: classification of technical quality attributes of Moscow underground (metro) services based on the Kano model

\begin{tabular}{|l|l|}
\hline $\begin{array}{l}\text { Category based on } \\
\text { the Kano model }\end{array}$ & $\begin{array}{l}\text { Technical quality attributes of Moscow underground (metro) } \\
\text { services }\end{array}$ \\
\hline Must-be (basic) & $\begin{array}{l}\text { Electronic display indicating the next station } \\
\text { Air conditioner } \\
\text { Availability of Wi-Fi } \\
\text { Separation of side seats by configuration or partition } \\
\text { Sound insulation } \\
\text { Space for strollers, bicycles and bulky luggage } \\
\text { Automatic door opening }\end{array}$ \\
\hline Attractive & $\begin{array}{l}\text { Feeling of air movement, light blow-off air } \\
\text { Window leaf/ possibility to open a window } \\
\text { The standard scheme of seat allocation ("sofas") }\end{array}$ \\
\hline One-dimensional & $\begin{array}{l}\text { Leaning seats } \\
\text { Seat type: soft, springy } \\
\text { USB charges for smartphones } \\
\text { Allocated space for standing } \\
\text { Informing about the load of cars for the arriving train } \\
\text { Pass-through between the train cars } \\
\text { Interactive panel for setting the route in the car }\end{array}$ \\
\hline Reverse & $\begin{array}{l}\text { Opening doors with a button } \\
\text { Luggage racks above the seats } \\
\text { Type of finish - fabric } \\
\text { Seats are arranged one behind the other (as in buses) }\end{array}$ \\
\hline Indifferent & $\begin{array}{l}\text { Configuration (wider seat spacing) } \\
\text { Increased glazing area } \\
\text { No luggage racks above the seats } \\
\text { Type of finish - leatherette }\end{array}$ \\
\hline Questionable & \begin{tabular}{l} 
Separation of seats with handrails \\
Temperature control \\
Vertical handrail in the center of the car \\
\cline { 2 - 5 } \\
Additional handrails at the edges and in the middle of the car \\
Additional board on the side of the carriage indicating the terminal station
\end{tabular} \\
\hline
\end{tabular}

A comparative analysis evaluating the importance of attributes and assigning them to appropriate categories based on the Kano model (one-dimensional, attractive, basic, indifferent, reverse, questionable) allows to group the technical quality attributes of
Moscow underground (metro) services according to the degree to which they need to be taken into account in order to increase the competitiveness of underground services. Five groups have been identified, as shown in table 8. 
Table 8: The degree to which the technical quality attributes need to be taken into account to increase the competitiveness of the service

\begin{tabular}{|c|c|}
\hline $\begin{array}{l}\text { The degree to which the } \\
\text { attributes need to be taken into } \\
\text { account }\end{array}$ & $\begin{array}{l}\text { Technical quality attributes of Moscow underground (metro) } \\
\text { services }\end{array}$ \\
\hline $\begin{array}{l}\text { Zero degree of necessity } \\
\text { The strategy is not to } \\
\text { introduce/eliminate }\end{array}$ & $\begin{array}{l}\text { New scheme of seat arrangement: one behind the other (as in buses) } \\
\text { Opening doors with a button } \\
\text { Vertical handrail in the center of the car } \\
\text { Luggage racks above the seats } \\
\text { Type of finish - fabric }\end{array}$ \\
\hline $\begin{array}{l}\text { First degree of necessity } \\
\text { Strategy: high priority of } \\
\text { implementing/monitoring the } \\
\text { quality }\end{array}$ & $\begin{array}{l}\text { Electronic display indicating the next station } \\
\text { Air conditioner } \\
\text { Availability of Wi-Fi } \\
\text { Sound insulation } \\
\text { Automatic door opening } \\
\text { Separation of side seats by configuration or partition } \\
\text { Space for strollers, bicycles and bulky luggage }\end{array}$ \\
\hline $\begin{array}{l}\text { Second degree of necessity } \\
\text { Strategies: implementation and } \\
\text { investment in the growth of } \\
\text { satisfaction are in the second place }\end{array}$ & $\begin{array}{l}\text { Leaning seats } \\
\text { Seat type: soft, springy } \\
\text { USB charges } \\
\text { Allocated space for standing } \\
\text { Informing about the load of cars for the arriving train } \\
\text { Pass-through between the train cars } \\
\text { Interactive panel for setting the route in the car }\end{array}$ \\
\hline $\begin{array}{l}\text { Third degree of necessity } \\
\text { Strategies: cost savings }\end{array}$ & $\begin{array}{l}\text { Configuration - wider seat spacing } \\
\text { Increased glazing area }\end{array}$ \\
\hline $\begin{array}{l}\text { Fourth degree of necessity } \\
\text { Strategies: additional study of } \\
\text { attributes }\end{array}$ & $\begin{array}{l}\text { Separation of seats with handrails } \\
\text { Temperature control } \\
\text { Lighting control by time of day } \\
\text { Additional handrails at the edges and in the middle of the car } \\
\text { Additional board on the side of the carriage indicating the terminal } \\
\text { station }\end{array}$ \\
\hline
\end{tabular}

Among the considered technical quality attributes of Moscow underground (metro) services, five groups of attributes are identified; the introduction of which can lead to an increase in passenger dissatisfaction. Attributes of the first degree of necessity are perceived as mandatory, must be present in metro and do not significantly affect the competitiveness of metro services.

The group of the second degree of necessity considers attributes aimed to increase underground services competitiveness covering the technical quality attributes of services that increase customer satisfaction. They are the second highest priority for implementation, regarded as investments in events aimed at increasing passenger satisfaction, and can significantly increase the competitiveness of underground (metro) services.

The strategy for the third-degree group of necessity is to save costs, because from the passengers' point of view, it is good if these attributes are present, but they do not have a big impact on passenger satisfaction and competitiveness.

The meaning of the attributes included in the fourth group is ambiguous. To substantiate their impact on passenger satisfaction and the competitiveness of metro services, it 
seems necessary to conduct additional research.

\section{Conclusion}

The authors' methodology developed and applied in this study allows us to offer sound management solutions aimed at increasing customer satisfaction with the technical quality of Moscow underground (metro) services as well as their competitiveness, taking into account the relative importance of attributes.

As a result of the proposed classification of attributes based on Kano's model and the author's methodology, several management decisions are proposed to improve the competitiveness of Moscow metro services as follows:

1. Increasing the availability of onedimensional attributes of the technical quality of Moscow metro services, and investing in monitoring the quality of their performance.

2. Investing in the implementation of important and attractive attributes of Moscow underground (metro) service quality for consumers.

3. Reducing the costs of introducing unimportant attributes, or introducing them gradually until, as the novelty for the market decreases, they will not pass into the category of one-dimensional or basic.

4. The value of the study attributes and their perception by consumers, according to the Kano's method, is ambiguous. Therefore, the authors suggest conducting experimental studies to determine the optimal car climate.

The results of the research conducted in the framework of the Kano model and the author's methodology showed that the life cycle of attributes within the framework of the Kano method is not enough studied in the literature (Lofgren, et al, 2008). Over time, attributes can shift from one category to another. For example, Wi-Fi availability in metro cars belongs to basic or onedimensional (mandatory) category; in Moscow Central Circle cars, they are also likely to move from the category of attractive attributes to the category of basic ones.

Therefore, periodic measurements of passenger satisfaction with the service attributes will allow predicting changes in the contribution of technical quality attributes of underground (metro) services to the assessment of passenger satisfaction and adjust the level of the technical quality of services and their competitiveness in advance.

\section{References}

- $\quad$ Berger, C. et al. (1993), Kano's Methods for understanding customer-defined quality, Center for Quality Management Journal, 1993, 2, 3-36.

- Best, R. (2-011), Marketing from the consumer. - M :: Mann, Ivanov and Ferber, 760.

- Cowell, D. (1984), The Marketing of Services. London: Heinemann.

- De, Oña J., De, Oña R., Eboli, L., Forciniti, C., Mazzulla, G.(2016), Transit passengers' behavioral intentions: the influence of service quality and customer satisfaction. Transportmetrica A: Transport Science,12(5), 385-412.

- Eboli, L, Mazzulla, G. (2012), Structural Equation Modellingfor Analysing Passengers' Perceptions about Railway Services. Procedia - Social and Behavioral Sciences, 54, 96-106.

- Friman, M., Fellesson, M. (2009), Service Supply and Customer Satisfaction in Public Transportation: The Quality Paradox . Journal of Public Transportation, 12(4), 57-69.

- Fraszczyk, A., Marinov, M. (2017), Sustainable Rail Transport. Proceedings of RailNewcastle ,307.

- Givoni, M., Rietveld, P. (2007), The access journey to the railway station and 
its role in passengers' satisfaction with rail travel. Transp Polic, 14(5), 357-65.

- Geetika, SN. (2010), Determinants of Customer Satisfaction on Service Quality: A Study of Railway Platforms in India. Journal of Public Transport, 13(1), 97113.

- Grönroos, Ch. (1998), Service Marketing Theory: Back to Basics. - Helsinki: SHS.

- Ibrahim, ANH., Borhan, MN., Md. Yusoff, NI., Ismail, A. (2020), Rail-based Public Transport Service Quality and User Satisfaction.. Promet - Traffic \& Transportation, 32, 3, 423-435.

- Ivashkova, N.I., Lopatinskaya, I.V., Grineva, 0.0. (2019), The quality of the rolling stock of the Moscow central ring: a study of passenger perception. Marketing and marketing research, 1 (135), 40-57.

- Jomnonkwao, S., Champahom, T., Ratanavaraha, V.(2020), Methodologies for Determining the Service Quality of the Intercity Rail Service Based on Users' Perceptions and Expectations in Thailand. Sustainability,12, 4259,20.

- Lopatinskaya, I.V., Lopatinsky, I.O., Sklyar, A.A.(2015), Measuring emotional loyalty: a modification of Kano's methodology to determine the impact of services on loyalty to the insurance company // Marketing and marketing research, 1, 42-59.

- Lukina, A.V., Skorobogatykh, I.I., Sidorchuk, R.R., Mkhitaryan, S.V., Kuznetsov, V.V. (2018), Study of satisfaction with the quality of transport services of the Moscow metro. // In the book: Managing the Development of Large-Scale Systems (MLSD'2018). Materials of the eleventh international conference. In 2 volumes. Under the general editorship of S.N. Vasilieva, A.D. Zvirkun, 82-84.
- Lofgren, M., Witell, L., Gustafsson, A. (2008), Two decades of using Kano's theory of attractive quality. A literature review, Quality Management Journal, 1,59-75.

- Mokronosov, A.G. (2014), Mavrina, I.N. (2014), Competition and competitiveness: a tutorial / A.G. Mokronosov, I.N. Mavrina. Yekaterinburg: Publishing house of Ural University, 194.

- Seifullaeva, M.E., Skorobogatykh, I.I., Sidorchuk, R.R., Shirochenskaya ,I.P. (2018), Foreign experience in studying the perceived quality of transport services (by the example of rail transport), Marketing in Russia and abroad, 5, 36-48.

- Seifullaeva, M.E., Skorobogatykh, I.I., Sidorchuk, R.R., Grineva, O.O. (2018), Assessment of the perceived quality of transport services: theoretical and practical approaches. Bulletin of the Russian Economic University named after G.V. Plekhanov, 2 (98), 122-134.

- Sidorchuk, R., Skorobogatykh, I . (2015), Marketing evaluation of public transport quality attributes: review of two waves of research, Mediterranean Journal of Social Sciences, 6 (3), 275-282.

- Sidorchuk, R., Efimova, D., Lopatinskaya, I., Kaderova, V. (2015), Parametric approach to the assessment of service quality attributes of municipal passenger transport in Moscow, Modern Applied Science, 9(4),303-311.

- Tsisar, A. (2002), Development and modification of goods and services - the Kano method // New marketing, 8, 1-14. 